\title{
TASAWUF FALSAFI DAN LOGIKA ARISTOTELIAN: TELAAH PEMIKIRAN IBN TAYMIYYAH
}

\author{
Muh. Ilham Usman \\ Sekolah Tinggi Agama Islam Negeri (STAIN) Majene \\ ilhamusman@stainmajene.ac.id
}

\begin{abstract}
Abstrak
Tulisan ini menyajikan hasil pemikiran Ibn Taymiyyah yang melakukan kritik terhadap tasawuf falsafi. Penelitian ini menggunakan pemikiran kajian tokoh yakni mengungkap gagasan dan ide yang pernah dilahirkan oleh seorang tokoh. Dengan menggunakan pendekatan historis yakni melihat sang tokoh sebagai manusia sejarah yang berkiprah dalam realitas sosial. Hasil kajian menemukan bahwa Ibn Taymiyyah tidak sepenuhnya anti-tasawuf. Ia sangat mengapresiasi beberapa sufi awal, hanya saja ia melancarkan kritiknya terhadap para tokoh tasawuf falsafi dan para pengamal tarekat yang berkembang pada zamannya yang hanya sibuk memikirkan akhiratnya. Ibn Taymiyyah melakukan kritik keras terhadap paham ittihad yang digagas oleh Yazid alBustami, kritik keras terhadap paham al-hulul yang diajarkan oleh Al-Hallaj, serta menolak paham wahdatul wujud yang digagas oleh Ibn 'Arabi.
\end{abstract}

Kata Kunci: Ibn Taymiyyah; Tasawuf; Ittihad; Hulul; dan Wahdatul Wujud.

\begin{abstract}
This article presents the thought of Ibn Taymiyyah who criticized Sufism. This research uses the idea of a figure study that reveals ideas and ideas that have been born by a figure. Using the historical approach that sees the character as a historical human being who is active in social reality. The results of the study found that Ibn Taymiyyah was not entirely anti-Sufism. He greatly appreciated some early Sufism, only to launch his criticism of the characters of the Sufism Falsafi and the thriving practitioners of his day who were only busy thinking of the end. Ibn Taymiyyah carried out harsh criticism of the Ittihad-givers initiated by Yazid al-Bustami, harsh criticism of al-Hulul's understanding taught by Al-Hallaj, and rejected the existence of the form of Ibn ' Arabi.
\end{abstract}

Keywords: Ibn Taymiyya, Sufism, Ittihad; Hulul; and Wahdatul Wujud.

\section{Pendahuluan}

Ibn Taymiyah ingin mengembalikan kejayaan Islam seperti sedia kala. Keinginan itu muncul lantaran menyaksikan umat Islam berada dalam kemunduran, akibat konflik kekuasaan dalam lingkungan dinasti Mamalik sepeninggal Raja Qalawun, Robinson (2019), Yusuf (2015), serta kehidupan yang hingar-bingar, penuh kemewahan di 
kalangan elit dan degradasi moral, Afrohah (2018) . Para agamawan hanya "sibuk" dengan pengejaran surganya masing-masing, tanpa mau tahu, dengan situasi dan kondisi masyarakat di bawah raja yang diktator. Di sisi lain, umat Islam mengidap penyakit takhayul, bid'ah dan khurafat akibat menjamurnya pengikut tasawuf falsafi dan tasawuf sunni (tarekat) Yazid (2017). Tidak ada inovasi atau ijtihad dalam rangka menguatkan agama Islam berhadapan dengan umat lain.

Pada kondisi inilah, Ibnu Taymiyah bercita-cita menciptakan masyarakat Islam yang sesuai dengan generasi salafusshaleh (tiga generasi: masa sahabat, tabi'in, tabi' tabi'in) sepeninggal Rasulullah Saw. Yaitu dengan berpedoman berdasarkan Al-Qur'an, Sunnah, dan perilaku hidup salafusshaleh. Dalam perkembangannya, Ibn Taymiyah mempunyai pandangan bahwa untuk mengembalikan kejayaan Islam, maka yang harus dilakukan adalah "menghidupkan Kembali ajaran ulama salaf yang shaleh", Burhanuddin (2016). Semua hal yang termasuk dalam kategori bid'ah, khurafat dan takhayul harus disingkirkan dalam masyarakat Islam, sebab kesemuanya inilah yang membuat umat Islam berada dalam kerangkeng taklid dan jumud, Esposito (2002). Ilmu kalam, filsafat Islam dan tasawuf menurut Ibn Taymiyah merupakan penyumbang terbesar dari terpecah dan lemahnya umat Islam masa itu. Ia pun mulai mempertanyakan dan mengkritisi filsafat dan tasawuf, bahkan membid'ahkan pelbagai rumusan pemecahan baru yang tidak ditemukan dalam ajaran salaf. Doktrin utama Ibn Taymiyah sesuai dengan ajaran Hanbali yang didasarkan pada supremasi Al-Qur'an, Sunnah, dan kaum salafiyyah sebagai otoritas tertinggi. Ia juga menerapkan penafsiran literal terhadap teks suci dan menilai praktik pemujaan wali dan ziarah ke makam wali adalah perbuatan bid'ah. Bahkan, dikemudian hari Ibn Taymiyah dijadikan sebagai ikon salafi, Krawietz (n.d.).

Ibn Taymiyah banyak menguasai ilmu pengetahuan, hal ini bisa dilihat dari hasil karangannya dalam berbagai disiplin pengetahuan. Dalam sejarah tertulis, Ibn Taymiyyah bolak-balik masuk penjara di Kairo, Alexandria dan Damaskus, total menghabiskan waktu sekitar enam tahun di penjara akibat kerasnya pemahaman teologi dan syariat, yang membuatnya kerap berseberangan dengan kaum elit hukum dan religius moderat dalam lingkungan pemerintahan, Robinson (2019, h. 265). Tanpa menafikan, pemenjaraan Ibn Taymiyah juga disebabkan seringnya melakukan protes sosial terhadap kebijakan raja saat itu. Seiring dengan perjalanan waktu, Ibn Taymiyyah banyak melahirkan murid dan 
kader yang pro terhadap pemikirannya, bahkan menjadi teman dalam berjuang, salah satunya Ibn Qayyim al-Jauziyah, Idris (2013, h.129). Hingga akhirnya, pada abad 18-19, Muhammad bin Abdul Wahhab, El Fadl (2005) kagum dan mengikuti tradisi pemikiran Ibn Taymiyah dalam mengembangkan pemikiran keagamaan di Arab Saudi dan lainnya. Muhammad bin Abdul Wahhab menjadi tokoh sentral dalam gerakan puritanisme, Rahmanu (2018, h.296).

Adapun tujuan penulisan ini untuk melengkapi kekurangan studi yang ada dengan cara memetakan secara seksama kritik Ibn Taymiyyah terhadap tasawuf dalam Islam, khususnya tasawuf falsafi. Tulisan ini berdasarkan pada argumen bahwa kritik Ibn Taymiyyah terhadap tasawuf tidaklah serampangan, melainkan dengan menggunakan argumen aqli dan naqli dalam menolak paham ittihad, hulul dan wahdatul wujud. Oleh karena itu, berdasarkan latar belakang di atas, permasalahan yang akan dikaji yakni mengapa Ibn Taymiyyah membenci paham tasawuf falsafi? Dan mengapa pula Ibn Taymiyyah mencap kaum sufi sebagai pelaku bid'ah?

\section{Metode Penelitian}

Penelitian ini merupakan pemikiran kajian tokoh yakni mengungkap gagasan dan ide yang pernah dilahirkan oleh seorang tokoh, Harahap (2006, h.4-5). Dalam mengungkap pemikiran tokoh ada dua hal yang mesti diperhatikan yakni objek material dan objek formal. Objek materialnya adalah gagasan dan ide yang pernah dilontarkan oleh sang tokoh. Olehnya itu, untuk mengkaji ide seorang tokoh, maka hasil goresan pena dan karya ilmiah lainnya dengan library research (kepustakaan). Sedangkan objek formalnya yakni ide seseorang yang sedang dikaji. Penelitian studi tokoh mengggunakan pendekatan historis yakni melihat sang tokoh sebagai manusia sejarah yang berkiprah dalam realitas sosial, Sabara (2019, h.276).

\section{Tasawuf Falsafi}

Secara etimologi, terdapat beberapa pendapat mengenai asal usul kata tasawuf/sufi, sufi berasal dari kata Safa artinya suci dan bersih. Ada juga yang mengatakan, sufi berasal dari kata Shaf artinya baris. Ada pula yang mengatakan bahwa sufi berasal dari kata Shuffah artinya serambi mesjid. Ada juga yang mengatakan bahwa 
kata sufi berasal dari kata Shafwah berarti orang-orang yang terpilih. Ada pula yang mengatakan bahwa sufi berasal dari kata Shuf berarti kain wol yang kasar.(Usman, 2015) Secara istilah, tasawuf merupakan metodologi yang membimbing manusia ke arah harmoni dan keseimbangan total. Inti pembahasan tasawuf menekankan kepada pembentukan karakter dan perilaku seseorang untuk menimalisasi ego.(Irham, 2018)

Kata tarekat berasal dari bahasa Arab, yaitu thariq atau thariqah, bentuk jamaknya tharaiq atau thuruq. Secara etimologi bermakna sistem atau metode (uslub), jalan atau cara (maslak). Tarekat menurut Trimingham tarekat adalah suatu metode praktis yang dijalankan para sufi dalam membimbing murid untuk merasakan hakikat Tuhan.(J. Spencer Trimingham, 1973)

Secara apik Louis Michon menjelaskan bahwa tarekat mengandung dua makna. Pertama, pengembaraan mistik pada umumya, gabungan seluruh ajaran dan aturan praktis yang bersumber pada al-Qur'an dan Sunnah, serta pengalaman guru spiritual (mursyid). Kedua, persaudaraan sufi yang dinamai sesuai pendirinya, seperti tarekat Qadiriyah diambil dari nama pendirinya Syekh 'Abdul Qadir al-Jilani, tarekat Naqsyabandiyah diambil dari nama pendirinya Syekh Muhammad bin Muhammad Baha' al-Din al-Uwaisi al-Bukhari Naqsyabandi.

Di sisi lain, para sarjana Eropa mengemukakan pendapat bahwa kata sufi berasal dari bahasa Yunani yakni sophos yang mempunyai arti kebijaksanaan, tetapi anggapan tersebut di tolak oleh Ibrahim Basyumi dengan mengatakan bahwa huruf sigma Yunani tidak sama dengan Sin Arab pada semua kalimat Yunani yang diarabkan, bukan huruf Shad. Jadi kalau kata sufi berasal dari bahasa Yunani, maka mencantumkan huruf Shad pada awalnya ini tidak sesuai dengan ketentuan yang seharusnya.(Ikalson, n.d.)

Dalam sejarah ilmu tasawuf, menurut Manhajuddin mengutip Muhammad Kurdu Ali dalam kitab al-Islam wa al-Hadarah al-Arabiyah bahwa orang yang pertama kali disebut sufi adalah Abu Hasyim yang tinggal di Kota Basrah, wafat 105 H.(Mahjuddin, 2012) Beliau disebut sufi karena banyak meluangkan waktunya untuk beribadah dan mendekatkan dirinya kepada Tuhan serta menjauhi kehidupan materialistik. Jika ditelisik lebih jauh, kata sufi pertama kalinya hanya digunakan untuk Abu hasyim dan kawankawannya di Basrah. Sedangkan orang-orang yang bergelut di dunia tasawuf di Syiria dan Mesir daerah lain biasa digelari zahud, ubbad, dan sebagainya. Pada abad I dan II H, 
pelekatan kata sufi berkaitan dengan cara/mode berpakaian Abu Hasyim yang menggunakan jubah dari wol/suf. cara berpakaian ini mengikuti tradisi para rahib Kristen Nestorian di kawasan Basrah yang sejak dulu telah menggunakan pakaian dari wol yang membuat kulit gatal.

Tasawuf muncul pada masa itu dipengaruhi beberapa factor, yakni (a). Respon atas pengaruh kekuasaan khalifah Bani Umayyah yang terlalu mementingkan kemewahan dunia. Para pejabat istana sibuk memperkaya diri dan berpoya-poya sehingga orangorang yang berorientasi "sufistik" kala itu membatin bahwa hal itu sudah sangat dari ajaran Islam yang telah diajarkan Rasulullah Saw. (b). Pertikaian antara kubu Khalifah Muawiyah dan Khalifah Ali bin Thalib yang berlanjut hingga keturunannya berdampak pada kondisi umat saat itu. Orang yang dulunya berpihak kepada keturunan Ali bin Abi Thalib dikejar dan melarikan diri hingga ke pelosok dunia oleh tentara dan keturunan Muawiyah, sehinga keturunan Ali bin Abi Thalib bersembunyi dari penguasa, hidup dalam asketik dan memperdalam ilmu tasawuf yang jauh dari hingar-bingar perpolitikan saat itu.(Mahjuddin, 2012)

Ada pula sumber sejarah yang mengatakan bahwa dalam perkembangan pengikut tasawuf seiring-sejalan dengan perkembangan Islam yang semakin berkembang, khususnya pada zaman Khalifah Umar bin Khattab. Pada masa ini, Imperium Persia berhasil ditaklukkan. Khususnya di daerah perbatasan, kondisi negeri yang tidak stabil dan labil secara politik - dalam arti, tahun ini menjadi wilayah Islam, tetapi kemungkinan tahun depan ditaklukkan dan menjadi wilayah imperium Bizantium - menjadi arena kontestasi perkembangan tasawuf ke masa berikutnya.

Oleh karena itu, di wilayah perbatasan tersebut sangat dibutuhkan penjagapenjaga yang kuat di daerah tersebut, sehingga daerah taklukan tidak lagi diambil oleh pihak musuh. Salah satu solusi dalam menjaga daerah tersebut, yakni dibutuhkan peran militer, akan tetapi, untuk "menurunkan" dan mengerahkan militer membutuhkan biaya yang sangat besar. Oleh sebab itu, jalan keluarnya adalah melakukan "transmigrasi" perpindahan penduduk kota Basrah, Kufah, Khurasan dan Damaskus ke daerah-daerah perbatasan dengan imbalan materi dan tanah yang menjanjikan. Tak dinyana, program ini diminati oleh banyak penduduk kota, salah satunya adalah orang-orang yang berorientasi 
tasawuf, yang rela meninggalkan ibukota kerajaan ke daerah perbatasan dengan niat ingin menjalani kehidupan yang sederhana dan asketik.

Dalam literature, para zuhad dan ubbad ini disebut sebagai Furzanun Mihrab. Salah satu tokoh zuhad yang terkenal yakni Abdullah bin Mubarak (sufi, komandan perang dan pedagang). Di sela-sela kesibukannya, ia mengumpulkan hadis-hadis yang berkaitan dengan zuhud dan jihad, menjadi dua kitab, yakni kitab zuhud dan kitab jihad. Buku ini ditulis untuk memberikan motivasi bagi orang yang tinggal diperbatasan.

Dengan demikian, program "transmigrasi" penduduk dari ibukota ke daerah perbatasan membuat perkembangan dan persebaran tasawuf menemukan momentumnya. Orang-orang yang berorientasi sufistik tidak hanya terdapat di ibukota, melainkan telah tersebar hingga daerah perbatasan. Khurasan merupakan daerah paling Timur dari kekhalifahan Abbasiyah, disana terdapat dua gerakan sufistik yang punya andil dalam penyebaran tasawuf, yakni Qaramita dan Malamatiyah. Qaramita adalah gerakan spiritual yang dipelopori oleh Muhammad ibn Qaram (wafat $255 \mathrm{H}$ ), orator dari Sijistan. Adapun ajarannya yang setiap manusia perlu hidup dalam keadaan sederhana dan memakai pakaian dari kulit domba yang belum disamak, dan harus bertawakkal dengan tidak boleh bekerja, hanya boleh mengemis dan meminta. Para pengikut Qaramita hidup di khanaqahkhanaqah kurang lebih 40 ribu yang tinggal di sana. Melihat perkembangan Qaramita, maka muncullah kritik yang dilancarkan oleh Malamatiyah yang dipelopori oleh Hamdun Bin Kassar dan Abu Hafs al-Haddad. Gerakan ini menekankan hidup sederhana dan menutup spiritual diri dari pandangan orang lain, dan berbanding terbalik dengan paham Qaramita. Gerakan spiritual ini banyak diikuti oleh Middle Class dan tempat berkumpulnya di Futuhah (Club/café tempat midlle class nongkrong). Gerakan ini sangat eksklusif, para pengikutnya harus mendaftar/menjadi member, harus ikut prosesi pengukuhan anggota dan ada hirarki member senior-junior. Inilah beberapa infrastruktur yang dilihat/diambil oleh kaum sufiyah di Baghdad, yakni dari kaum Qaramita (khanaqah) dan dari kaum Malamatiyah (ada member, ada prosesi pengukuhan member, dan hirarki member senior dan junior).

Selain itu, institusi pendidikan Nizahmiyah yang didirikan oleh perdana menteri Nizham al-Muluk juga menyumbang kontribusi dalam perkembangan tasawuf di dunia Islam. Nizham al-Muluk mempunyai pandangan bahwa melahirkan sebuah negara yang 
kuat dan tertata bagus diperlukan institusi hukum yang kuat, sehingga beliau menggandeng para fuqaha atau jurist untuk berkontribusi dalam pemerintahan. Selain itu, Nizham al-Muluk menganggap penting sebuah negara mempunyai "korps para jurist, hakim dan pengacara" untuk menjadi birokrat dan mengisi kekosongan di institusi hukum. Sehingga dengan ini, Nizham al-Muluk mendirikan institusi pendidikan di berbagai kawasan kerajaan, antara lain: Nizhamiyah Bagdad, Nizhamiyah Naisapur/Khurasan, dll.

Dalam perkembangannya, banyak guru dan murid di Nizhamiyah yang tertarik terhadap Tasawuf, salah satunya Imam Al-Ghazali yang kala itu "ngajar" di Nizhamiyah Baghdad, walaupun akhirnya keluar dan melakukan pengembaraan spiritual, dan juga kembali "ngajar" di Nizhamiyah Naisapur Khurasan, dan kembali ke kampung halamannya, Thus, membangun khanaqah.

Thabaqat adalah buku kumpulan yang berisi identitas para tokoh fiqh pada zaman itu. Thabaqat inilah yang "ditiru" dan "masuk-merangsek" ke dunia tasawuf, sehingga As-Sulami menulis tentang Thabaqat Sufiyyah sebuah buku yang berisi kumpulan para tokoh-tokoh sufi, yang dulu dan zaman dulu -tidak pernah mengganggap dirinya sebagai sufi - dimasukkan sebagai tokoh sufi, misalnya pendiri gerakan Qaramita dan Malamatiyah. Begitu pula Abdullah bin Mubarak -tidak pernah menganggap dirinya sufi - tetapi, dimasukkan oleh penulis Thabaqat Sufiyyah sebagai salah satu seorang tokoh yang berkecimpung dalam tasawuf/sufi, hingga tokoh tabi'in dan bahkan ke masa sahabat.

Selain itu, Nizhamiyah memberikan kontribusi pada dunia tarekat yakni pemberian ijazah. Lewat Nizhamiyahlah, para umat Islam yang belajar di lembaga Nizhamiyah setelah sekian lama dan tamat akan diberikan ijazah oleh gurunya, bukan lembaga institusi pendidikan seperti sekarang. Ijazah yang dikeluarkan oleh guru sebagai keterkaitan pengetahuan antara sang guru dan sang murid. Hal ini pulalah yang diadopsi oleh tasawuf, bagi orang yang belajar tasawuf, setelah tuntas dalam pembelajarannya diberikan ijazah/izin untuk mengajarkan pengetahuannya tersebut ke orang lain.

Inilah beberapa unsur yang memberikan kontribusi pada perkembangan tasawuf dan tarekat hingga menjadi sebuah organisasi sufi yang matang hingga detik ini. Khanaqah/zawiyah (pusat kegiatan), pengukuhan anggota, bai'at, hirarki keanggotaan, 
thabaqat/silsilah dan ijazah, kesemuanya inilah yang diadopsi dari luar lingkaran tasawuf masuk ke tasawuf hingga menjadi ordo sufi tarekat.(Mahjuddin, 2012)

Pada VI-VII H, sudah mulailah berdiri tarekat Qadiriyah yang dinisbatkan ke Syekh Abdul Qadir al-Jilani (w. akhir 561 H), tarekat Rifaiyyah yang dinisbatkan ke Syekh Ahmad bin Abi al-Hasan bin 'Ali bin Rifa'ah al-Husayni (w. 578 H), tarekat Suhrawardiyah yang dinisbatkan ke Syekh Abu al-Futuh Yayhya bin Habash bin 'Amirak al-Suhrawardi yang dihukum mati oleh Malik al-Zahir (Putra Sahuddin al-Ayyubi). Di samping itu, muncul juga seorang sufi yang non-tarekat, seperti Muhyiddin ibn 'Arabi, Fariduddin al-Attar, Umar bin Farid, Jalaluddin al-Rumi.

Dalam perkembangan tasawuf, corak tasawuf terbagi dua, yakni tasawuf akhlaki atau biasa disebut tasawuf sunni dan tasawuf falsafi. Tasawuf sunni adalah tasawuf yang dianggap sesuai dengan ajaran Alqur'an dan Sunnah Nabi Saw., maksudnya peningkatan kualitas diri kepada Allah terlebih dahulu seorang calon sufi harus memahami syari'at dengan sebaik-baiknya, misalnya ia harus mempelajari fikih dalam segala bidangnya secara baik dan benar sesuai dengan ajaran yang telah dirumuskan oleh madzhab alarba'ah. Tokoh-tokoh tasawuf sunni yang populer adalah al-Junaid al-Baghdadi, alQusyairi, dan al-Ghazali, dan dalam perkembangannya tasawuf sunni mengambil bentuk praktis berupa tarekat dan ketiga tokoh inilah yang lebih banyak mengilhami dasar-dasar ajaran tarekat yang ada sekarang ini. Sedangkan tasawuf falsafi adalah tasawuf yang ajaran-ajaran dan konsepsinya disusun secara mendalam dengan bahasa-bahasa yang simbolik-filosofis. Sehingga tidak heran apabila mayoritas sufi yang mempunyai paham tasawuf ini mengalami sikap ekstasi (kemabukan spiritual) dan mengeluarkan statement yang terkesan tidak awam (syathahat). Seperti yang diucapkan Ibn 'Arabi dengan slogan "Ana al-Haqq". Tokoh-tokoh lainnya antara lain Abu Yazid al-Busthami, al-Hallaj, Ibn 'Arabi, al-Jilli dan sebagainya.(Faza, 2019)

\section{Kritik Terhadap Tasawuf Falsafi}

Nurcholish Madjid (Cak Nur) menulis secara gamblang tentang kritik Ibn Taymiyah terhadap tasawuf:

"Tidak saja dalam bidang politik Ibn Taymiyah tercampur antara keprogresifan dan kekolotan. Berkenaan dengan sufisme pun Ibn Taymiyah menganut paham yang agak kompleks. Ibn Taymiyah sangat terkenal sebagai pemikir yang menentang habis-habisan 
praktik umum mengagungkan makam tokoh yang disebut wali, serta banyak praktik kesufian lainnya. Namun, sesungguhnya Ibn Taymiyah tetap mengakui keabsahan tasawuf dan berbagai pengalaman kesufian seperti kasyf (penyingkapan intuitif akan tabir kebenaran). Tetapi, Ibn Taymiyah ingin membawa pengalaman memperoleh kasyf itu kepada tingkat proses intelektual yang sehat, dan dengan tegas ia menolak finalitas kasyf sebagai bentuk penemuan Kebenaran atau Tuhan. Menurut Ibn Taymiyah, keabsahan kasyf "adalah sebanding dengan kesucian moral pada jiwa, yang tingkatan-tingkatan kesucian itu, sebenarnya, tidak ada batasnya". Maka kasyf pun ada dalam tingkat-tingkat yang berkelanjutan tanpa batas. Bagi Ibn Taymiyah, mencapai pengetahuan sempurna tentang Kebenaran Mutlak atau Tuhan adalah mustahil. Dengan begitu sesungguhmya Ibn Taymiyah adalah semata-mata seorang penganut suatu paham kesufian baru (NeoSufisme) yang dipandangnya lebih sesuai dengan semangat dasar ajaran al-Qur'an, bahkan dialah pelopornya", Madjid (1983, h. 42-43).

Dalam tulisan Cak Nur menjelaskan bahwa Ibn Taymiyah mengiritik tasawuf disebabkan begitu banyaknya praktik tasawuf yang tidak berdasar dari Al-Qur'an dan Sunnah Nabi Muhammad Saw, tetapi di sisi lain Ibn Taymiyah juga mengakui keabsahan tasawuf tetapi yang dipraktikkan oleh para pendahulunya. Penolakan Ibn Taymiyah kepada tasawuf berlandaskan bahwa perbuatan dan tindakan tersebut tidak pernah dilakukan pada masa Rasulullah Saw dan sahabat-sahabatnya.

Para cendekiawan dalam banyak tulisannya menjadikan sosok Ibn Taymiyah sebagai sosok yang disimbolkan sebagai tokoh dan pelopor anti-tasawuf hingga dewasa ini. Hal ini dikarenakan sosok Ibn Taymiyah dalam menggencarkan anti-tasawuf secara lisan, ia juga banyak melahirkan karya tulis yang menentang tasawuf, diantaranya Majmu Rasa'il Wa Masa'il, Minhaj al-Sunnah al-Nabawiyah Fi Naqd Kalam al-Syi'ah Wa alQadariyah, Muwafaqat Sahih Al-Manqul Li Sarih Al-Ma'qul, Majmu al-Fatawa, dan lain sebagainya.

Dalam disertasi Muhammad Abdurrahman al-Uraifi mengatakan bahwa Ibn Taymiyah membaca kurang lebih 43 buku primer tasawuf, untuk melakukan kritik terhadapnya, Al-Uraifi (n.d, h. 133). Lebih lanjut, al-Uraifi menjelaskan bahwa dalam kitab Majmu Fatawa Ibn Taymiyah banyak didapatkan "keraguan jawaban" dalam menjawab persoalan-persoalan, hal ini bisa dilihat adanya kata "azunnu" (saya duga) dalam kitab tersebut.

Ibn Taymiyyah dijadikan sebagai sumber rujukan dalam menolak tasawuf dewasa ini, disebabkan pula telah berkembangnya kelompok salafi-wahabi di dunia Islam yang diprakarsai oleh Muhammad Abdul Wahhab. Tokoh yang disebut terakhir ini, terinspirasi 
dari pemikiran Ibn Taymiyyah, baik dalam bidang akidah/kalam, fiqh, dan tasawuf, dengan mengatakan bahwa tasawuf menjadi bid'ah disebabkan adanya institusi tarekat yang menjamur di dunia Islam, tetapi tidak pernah dipraktekkan pada zaman Nabi Muhammad Saw dan masa para sahabat, Kholil (2017). Bahkan ditemukan beberapa risalah Ibn Taymiyyah yang ditulis dengan tangan Muhammad bin Abdul Wahhab di museum Inggris, Ali (1995).

Bahkan cendekiawan Islam popular abad XIX, Fazlur Rahman mengatakan bahwa tulisan-tulisan Ibn Taymiyah perlu dipertimbangkan karena beberapa hal, pertama, karena kajian menyeluruh terhadap tulisan-tulisan Ibn Taymiyah mempunyai tujuan untuk memperbaiki dan secara intelektual merekonstruksi masyarakat Islam normatif terdahulu yang didasari oleh Al-Qur'an dan Hadits. Kedua, karena Ibn Taymiyah mengingatkan kita bahwa di abad-abad terakhir Islam, kira-kira menjelang abad ke-4 H, perkembangan Islam di segala bidang, seperti fiqih, kalam, tasawuf dan politik, mulai mengalami ketidaktentuan dan secara perlahan berkembang menjadi tak terkontrol, Ibn Taymiyah menyebutnya dengan neo-fiqih, neo-kalam, neo-tasawuf, dan neo-politik, Rahman (1992). Olehnya itu, untuk membuat perbaikan dan perubahan mestilah dikenali titik kesalahan-kesalahannya, ia mengatakan:

“(ini melengkapi) dasar untuk keharusan (menggunakan) jalan lurus dan tengah dan bagaimana mengikuti al-Qur'an dan sunnah (secara benar) yang berkenaan dengan nama-nama Tuhan, sifat-sifat-Nya dan kesatuan-Nya dalam ucapan maupun keyakinan; di samping itu juga menunjukkan bahwa Al-Qur'an dan sunnah mengandung segala petunjuk dan bahwa munculnya bid'ah terjadi akibat melepaskan bagian-bagiannya (artinya petunjuk al-Qur'an dan sunnah)...Dasar yang menyebabkan semua ini, adalah karena bagian dari kebenaran telah ditinggalkan, sedangkan bagian dari kesalahan di ambil (dan setelah pembekuan pandangan) kebenaran secara sengaja disembunyikan kemudian kebenaran dan kekeliruan itu dicampuraduk", Rahman (1992, h. 187).

Di Indonesia, apresiasi terhadap gagasan Ibn Taymiyyah juga muncul dari beberapa cendekiawan Islam, diantaranya Nurcholish Madjid (Cak Nur). Cak Nur mengikuti jejak gurunya Fazlur Rahman dapat dilihat dalam disertasinya di Chicago University Ibn Taimiyya on Kalam and Falsafa: A Problem of Reason and Revelation in Islam, dan ia pun menulis:

"Saya tertarik kepada Ibn Taymiyah karena peranannya yang sering dipandang sebagai leluhur doktrinal bagi banyak sekali gerakan-gerakan pembaruan Islam 
zaman modern, baik yang fundamentalistik maupun yang leberalistik. Saya berkeyakinan bahwa jika ummat Islam, khususnya mereka yang merasa menganut atau diilhami oleh pikiran-pikiran Ibn Taymiyah, mewarisi dan mengembangkan tradisi intelektualnya itu, dapat diharap akan banyak diketemukan jalan keluar dari berbagai kemacetan pemikiran zaman sekarang ini. Jalan keluar itu, dari berbagai segi, akan memiliki tingkat keontentikan yang tinggi, yang bakal membawa umat Islam memasuki abad modern dan berpartisipasi di dalamnya secara mantap tanpa banyak halangan doktrinal...", Baso (2006, h. 213-214)

Ibn Taimiyyah dianggap tokoh anti-tasawuf disebabkan beberapa karya-karyanya mengilhami atau menginspirasi golongan atau aliran yang anti tasawuf, serta rela keluarmasuk penjara demi mempertahankan prinsipnya dan mengalami langsung pergesekan keras dengan kaum sufi hingga di penjara di Alexandria berkaitan dengan fatwa yang menyalahi jumhur tentang "larangan berziarah kecuali ke tiga masjid", Kholil (2017).

Ibn Taymiyah mengeritik kepada orang yang yang mengatakan fana', ittihad, hulul dan wahdatul wujud merupakan ajaran Islam. Ia mengatakan bahwa kesemuanya adalah perilaku yang tidak pernah dilakukan oleh Nabi Muhammad Saw dan para sahabatnya, Washil (2018). Ibn Taymiyah mengeritik para sufi dengan cara mengingatkan kesalahan yang sering terjadi yang menyangka bahwa fana ' berarti ittihad. Seorang pecinta tidak akan mungkin bersatu dengan yang dicintainya, menjadi jiwa yang tunggal. Ibn Taymiyah menyatakan bahwa makhluk dapat bersatu dengan sang Khaliknya merupakan pandangan yang sesat, dikarenakan al-Haqq sama sekali tidak menyatu dengan sesuatu apapun. Secara nalar, dua benda tidak bisa menyatu dengan benda lain, kecuali jika salah satu dari benda itu telah berubah dan hakikatnya sudah rusak. Jika pun sudah menyatu, hasil penyatuan itu tentunya berbeda dengan asal keduanya benda tersebut, Al-'Asimiy‘ (1398).

Ibn Taymiyah juga memandang mereka sebagai orang yang lebih sesat dari pada orang Yahudi dan Kristen. Ia mengatakan demikian atas dasar dua sebab. Pertama, penganut paham ittihad ini mengatakan, "Allah Swt itu menyatu dengan hamba yang Dia pilih." Sementara orang Yahudi dan Nasrani mengatakan, "Tuhan tetaplah Tuhan, dan Dzat selain Dia bukanlah Tuhan”. Kedua, orang-orang Nasrani mengatakan bahwa hanya orang yang mereka agungkan saja yang bisa menyatu dengan Allah Swt, seperti al-Masih.

Maka Ibn Taymiyah mengatakan bahwa orang yang berpandangan ittihad merupakan hal yang batil. Ibn Taymiyah menegaskan: 
"Barang siapa yang berkata sesungguhnya Allah Swt berfirman pada lisan alHallaj dan ucapan yang didengar dari al-Hallaj adalah firman Allah Swt atau Allah Swt adalah yang berfirman lewat lisan al-Hallaj adalah kafir menurut konsensus kaum Muslimin. Karena sesungguhnya Allah Swt tidak bertempat pada diri makhluk dan tidak berbicara lewat lisan makhluk melainkan mengutus utusan membawa firman-Nya lalu mereka menyampaikan apa yang diperintahkan Allah Swt kepada mereka lewat lisan para Rasul itu, sebagaimana sabda Nabi Muhammad Saw: bahwa sesungguhnya Allah Swt berfirman pada lisan Nabi-nya dan Allah Swt Maha Mendengar terhadap orang yang memuji-Nya, Ibn Taymiyyah (n.d., 31).

Ibn Taymiyyah tidak hanya anti terhadap paham ittihad, melainkan juga terhadap orang yang menganut pandangan hulul, Ibn Taymiyah menolak keras pandangan tentang bersemayamnya Allah Swt dalam jasad makhluk, karena agama juga menolak pandangan ini, pandangan hulul sebenarnya adalah pandangan Kristen yang meyakini bersemayannya Tuhan dalam diri makhluk. Ia mengatakan:

"Hal itu tidak dimaksudkan bahwa Allah berada di dalam hati hamba-hamba-Nya. Yang ada dalam hati hamba adalah ma'rifat, cinta, dan ibadah kepada Allah. Bandingkan dengan keadaan orang yang sedang tidur. Dalam tidurnya ia bermimpi melihat seseorang yang bercakap-cakap dengannya. Orang yang dilihatnya dalam mimpi itu bisa jadi orang yang tinggal serumah dengannya, atau orang yang sudah mati. Yang disaksikan dalam mimpi itu bukanlah orang yang sebenarnya, tetapi orang yang serupa dengannya atau gambarnya. Demikian juga, manusia melihat matahari, bulan, dan binatang, atau benda-benda lain dalam cermin. Benda-benda dalam cermin itu menjadi besar atau kecil sesuai dengan ukuran cermin, menjadi bundar atau bersih tergantung cermin. Semua itu hanyalah gambar yang terpantul dalam cermin, bukan benda yang sesungguhnya. Adapun esensi matahari yang berada di langit tidaklah bisa menyatu di dalam cermin itu", Ibn Taymiyah (n.d., h. 96).

Berkaitan dengan paham ittihad dan hulul, Imam Al-Ghazali juga menolak pandangan tersebut dengan mengatakan bahwa seseorang yang melakukan penyatuan berupa ittihad dan hulul adalah sebuah kesalahan yang nyata, manusia hanya mampun mengenal Tuhannya dengan ma'rifah yakni mengenal Tuhan dengan penuh perasaan jiwa sebagai seorang hamba dengan tidak terjebak pada penyatuan, Iswahyudi (2017).

Sedangkan terhadap orang yang berpandangan Wahdat al-Wujud, Ibn Taymiyah sangat menolak, Washil (2017). Ibn Taymiyyah mengklaim pengikut doktrin ini jauh lebih kafir daripada orang Kristen karena beberapa sebab, pertama, karena inti dari perkataan mereka adalah bahwa Allah Swt tidaklah menciptakan apapun. Karena jika 
semua yang wujud itu tidak lain adalah wujud-Nya, maka tidaklah mungkin Ia menciptakan Dzatnya sendiri. Sudah merupakan perkara yang tidak dapat dipungkiri oleh akal bahwa sesuatu itu tak mungkin menciptakan dirinya sendiri. Setiap ciptaan pasti ada yang menciptakanya. Bahkan orang-orang musyrikpun meyakini itu. Kedua, bagi mereka, Allah Swt itu tidak member rizki, karunia, kasih sayang, nikmat, ilmu, petunjuk, dan manfaat kepada siapapun, sebab hakikatnya menurut pengikut paham ini mereka adalah wujud Allah Swt sendiri. Ketiga, menurut mereka, yang bersujud, rukuk, beribadah, berpuasa, merasakan lapar, tidur, mengalami sakit, dan diserang oleh musuh itu adalah Allah Swt sendiri. Karena semua yang ada ini Adalah Allah Swt. Maka ketika ada yang terbebas dari musibah ini adalah Allah Swt. Keempat, bagi mereka, yang menyembah Lata, Uzza, bintang, Isa, Uzauir dan para malaikat itu adalah Allah sendiri. Karena yang ada ini, baik yang melakukan ketaatan dan kekufuran sesungguhnya adalah Allah Swt juga, Ibn Taymiyyah (n.d.).

Singkatnya, Ibn Taymiyyah menentang keras tasawuf Ibn 'Arabi karena metode dan thariqah yang dipakai sebagai perjalanan ke arah penyingkapan cahaya Ilahi, melalui pengunduran diri (khalwat) dari kehidupan ramai, Madjid (2000, h. 262). Hal ini tidaklah disetujui oleh Ibn Taymiyyah karena kekhusyu'an yang berlebihan dalam ibadah hanyalah menjauhkan seseorang dalam kehidupan sosialnya dan ini merupakan ciri dari biarawan Kristen. Dari sini, kita dapat melihat bahwa Ibn Taimiyyah sangatlah empirik dalam melihat segala sesuatu.

Dalam perkembangannya, Ibn Taymiyah melakukan kritik terhadap filsafat, ia melakukan dua hal sekaligus, yakni dekonstruksi dan rekonstruksi. Ketidaksepakatan Ibn Taymiyah terhadap filsafat ditunjukkan dalam meruntuhkan logika Aristoteles, Hallaq (1993). Kemudian menyusun logika Islam yang sejalan dengan Al-Qur'an dan Sunnah. Ibn Taymiyah melakukan dekonstruksi dengan cara membongkar kepalsuan logika Aristoteles yang banyak menguasai pikiran intelektual dan cendekiawan Islam kala itu, Madjid (1983). Dalam kritiknya kepada logika formal, Ibn Taymiyah antara lain menolak kebenaran demonstrasi atau burhani yang menurut anggapan para filosof merupakan bentuk bukti tertinggi. Ibn Taymiyah tidak mempersoalkan proses silogistis yang dapat menghasilkan bukti tak terbantah, tetapi ia melihat bahwa cara berpikir demonstrasi itu sangat hampa, Rayan (2012), Rayan (2011). 
Ibn Taymiyah membangun metode-metode ilmu agama dan sekaligus mengiritik logika Aristoteles dengan menggunakan teori al-tajribah al-hissiyah (metode empiris), al-mutawatirat (kabar dari mayoritas orang), dan istiqra' (penalaran induktif), Burhanuddin (2018), Firdaus (2014). Kritik ini muncul disebabkan Ibn Taymiyah hidup di zaman kebebasan berpikir telah memunculkan berbagai aliran dan sekte yang melemahkan umat Islam dari serangan dan rongrongan tentara Mongol. Hal ini diakibatkan oleh para cendekiawan dan pemikir Islam terpengaruh oleh "pengetahuan dari luar Islam” sehingga “menghancurkan” akidah Islam.

Kritik Ibn Taymiyah terhadap terhada logika Aristoteles telah mendorongnya kepada literalisme dalam Kitab Suci dan membuatnya menolak dengan keras interpretasiinterpretasi rasional, khususnya interpretasi yang dilakukan dengan menggunakan bahanbahan asing (bukan Islam) seperti hellenisme, baik pada ilmu kalam maupun filsafat. Inilah pangkalnya Ibn Taymiyah menolak dengan keras kedua tradisi intelektual Islam itu. Dalam hal ini, ia hanya bertindak sepenuhnya selaku pelanjut metode Ahmad ibn Hanbal (w. 241 H/855 M) dan Dawud Khalaf "Literalis" (al-Zhahiri, w. 269 H/882 M), tetapi dengan argumentasi dan sistematika yang lebih unggul, Madjid (1983).

Di samping itu, kritik Ibn Taymiyyah terhadap logika Aristotelian mengenai definisi sebagai Pergenus et Differentia serta teori silogismenya dengan berargumen bahwa pengetahuan tidak bisa dibatasi pada penalaran silogistik saja. Penalaran deduktif hanya merupakan kegiatan intelek dan tidak ada hubungannya dengan realitas fisik yang sebenarnya. Maka penalaran deduktif tidak bisa menghasilkan pengetahuan yang berguna, harus empiris dan faktual, dengan kata lain harus induktif bukan deduktif, Abidin (2010). Kelemahan logika Aristoteles terletak hanya pada kontemplasi pikiran saja, tanpa observasi-empiris dan menawarkan metode realis-empiris sebagai pengganti logika tradisional, Kurnianto (2014). Dengan demikian, silogisme tidak memberikan faedah keilmuan sebab apa yang mungkin diketahui melalui silogisme, hakekatnya sudah diketahui tanpa silogisme. Dan juga silogisme Aristoteles berkaitan dengan metafisika hanya membahas apa yang ada di dalam pikiran, namun tidak ada di dalam realitas.

Ibn Taymiyah dikenal seorang ulama yang sangat keras menentang filsafat dan mengatakan para filosof sebagai ahli bid'ah. Ia mendasari tuduhannya dari perkataan arRazi yang berbunyi: "Ketika dalil 'aql dan naql saling bertentangan, atau ketika teks naql 
dengan realita akal saling bertentangan maka kemungkinan pemecahannya ada beberapa macam: a. Adakalanya dengan memadukan keduanya, dan ini jelas-jelas tidak mungkin; b. Atau menolak kedua-duanya, dan hal ini pun juga tidak mungkin; c. Atau dengan mengedepankan naql/teks, ini pun juga tidak mungkin, karena akal adalah sumber teks, apabila kita mendahulukan naql maka hal ini merupakan suatu bentuk penghinaan terhadap akal yang merupakan sumber naql, dan penghinaan terhadap sumber sesuatu merupakan penghinaan terhadap sesuatu itu sendiri, maka pendahuluan naql merupakan penghinaan terhadap akal dan naql; d. Maka wajib mendahulukan akal untuk selanjutnya naql/teks mungkin ditakwilkan dan kalau tidak mungkin maka ditiadakan”.

Kritik yang dilancarkan Ibn Taymiyah tidaklah membabi-buta, ia lebih banyak mengkritik terhadap tasawuf falsafi dan tarekat-tarekat yang menjamur di dunia Islam. Di sisi lain, ia mengapresiasi tasawuf yang dikembangkan oleh Harist al-Muhasibi, Syekh Junaid al-Bagdadi, dan Syekh Abdul Qadir al-Jilani, Kholil (2017), Syaikh Ibrahim ibn Adham ra, Syaikh Ma'ruf al Karkhi ra, Syaikh Hasan al-Basri ra, Sayyidah Rabi'ah alAdawiyyah ra, Syaikh Ahmad ar-Rifa'i. Hal ini bisa dilihat dalam kitab Majmu al-Fatawa Ibn Taymiyah berkaitan dengan kritiknya terhadap para pelaku tasawuf. Kitab Majmu' al-Fatawa Ibn Taymiyah yang dikumpulkan atau disusun 'Abd. al-Rahman bin Muhammad bin Qasim al-'Asimiy al-Najdiy al-Hanbaliy bersama putranya yang bernama Muhammad. Kitab ini terdiri dari 37 jilid yang merupakan kumpulan fatwa dari berbagai kitab, surat, dan pendapat- pendapat yang ia hadapi pada masanya. Selanjutnya editor kitab ini melakukan perjalanan (rihlah) ke berbagai negera seperti Paris, Mesir, Syam, Damaskus, Bagdad dan beberapa negara lainnya untuk mengumpulkan tulisan Ibn Taymiyah. Kitab ini pertama kali dicetak pada tahun 1374 H atas saran Raja Saudi dan telah dicetak ulang beberapa kali. Cetakan terakhir dan paling komprehensif diterbitkan di Saudi Arabia dalam 37 jilid, termasuk jilid ke tiga puluh tujuh yang berisi indeks, Ahmad (2019, h. 179-180). Adapun isi/jilid dari kitab Majmu al-Fatawa Ibn Taymiyah, sebagai berikut (1). Tentang Kitab Tauhid al-Rububiyah; (2). Tentang Kitab Tauhid alUluhiyyah wa al-Ra'd 'Ala Ittisal al-Hulul wa al-Ittihad; (3). Tentang Kitab Mujmal I'tiqad al-Salaf; (4). Tentang Kitab Mufasal al-I'tiqad; (5). Tentang Kitab al-Asma' wa al-Sifat; (6). Tentang al-Juz al-Sani min Kitab al-Asma wa al-Sifat; (7). Tentang al-Iman; (8). Tentang al-Qadr; (9). Tentang al-Mantiq; (10). Tentang 'Ilm al-Suluk; (11). Tentang al-Tasawwuf; (12). Tentang al-Qur'an Kalamullah Haqiqatuhu; (13). Tentang Kitab 
Muqaddimah al-Tafsir; (14). Tentang Kitab Tafsir al-Juz' al-Awwal Min Surah alFatihah Ila Surah al-A'raf; (15). Tentang Kitab Tafsir al-Juz' al-Tsani Min Surah alA'raf Ila Surah al-Zumar; (16). Tentang Kitab Tafsir al-Juz' al-Tsalis Min Surah alZumar Ila Surah al-Ikhlas; (17). Tentang Kitab Tafsir al-Juz' al-Rabi' Min Surah alIkhlas wa al-Mauzatain; (18). Tentang Kitab al-Hadis; (19). Tentang Kitab Usul al-Fiqh Juz al-Ittiba'; (20). Tentang Kitab Usul al-Fiqh Juz' al-Sani al-Tamazhub; (21). Tentang Kutub al-Fiqh al-Juz al-Awwal al-Taharah; (22). Tentang Kutub al-Fqih al-Juz al-Sani al-Salat; (23). Tentang Kutub al-Fiqh al-Juz al-Tsalis sujud al-Sahwi Ila Salat al-Aghzar; (24). Tentang Kutub al-Fiqh al-Juz al-Rabi' Min Salat ahl al-A'zari Ila al-Zakat; (25). Tentang Kutub al-Fiqh al-Juz al-Khamis al-Zakat wa al-Saum; (26). Tentang Kutub alFiqh al-Juz al-Sadis al-Haj; (27). Tentang Kutub al-Fiqh al-Juz al-Sabi' al-Ziyarah wa Syad al-Rihal Ilaiha; (28). Tentang Kutub al-Fiqh al-Juz al-Samin al-Jihad; (29). Tentang Kutub al-Fiqh al-Tasi' al-Baiy; (30). Tentang Kutub al-Sulh Ila al-Waqt; (31). Tentang Kitab al-Waqt Ila al-Nikah; (32). Tentang al-Nikah; (33). Tentang Kitab alTalaq; (34). Tentang Kitab al-Zihar Ila al-Qital Ahl al-Baqa'; (35). Tentang Kitab alQital Ahl al-Baqa Ila Nahayah al-Iqrar; (36). Tentang al-Faharis al-Ammah wa alTaqrib; dan (37). Tentang al-Faharis al-Ammah wa al-Taqrib.

Pendek kata, Ibn Taymiyah tidak menolak tasawuf secara keseluruhan, ia hanya menolak para pelaku tasawuf falsafi dan pengikut tarekat yang banyak menyibukkan dirinya untuk berzikir di tengah kondisi dan situasi "kemunduran" umat Islam. Ibn Taymiyyah tidak menyerang tasawuf secara babi-buta, tetapi hanya melakukan purifikasi tasawuf yang menyimpang sekaligus membuat standar tasawuf yang berpijak pada sumber autentik Islam, Zamzami (2017). Seharusnya, para ulama tasawuf tersebut bangkit dan bergerak "merubah" keadaan umat Islam yang sedang dilanda "keterpurukan" akibat serangan bangsa Mongol. Umat Islam harus bangkit seperti di zaman kejayaannya.

Apresiasi dan penghargaan terhadap ajaran-ajaran tasawuf ia torehkan dalam tulisannya di kitab Majmu al-Fatawa dalam bab tasawuf:

"Kalian harus mengetahui bahwa para syaikh yang terbimbing harus diambil dan diikuti sebagai petunjuk dan teladan dalam agama, karena mereka mengikuti jejak Para Nabi dan Rasul. Thariqah para syaikh itu adalah untuk menyeru manusia kepada kehadiran dalam Hadhirat Allah dan ketaatan kepada Nabi”, Al-'Asimiy' (1398, h. 497). 
Kemudian dalam kitab yang sama, Ibn Taymiyah melanjutkan pujian dan penghargaannya kepada para ulama yang berorientasi sufi:

"Para syaikh harus kita ikuti sebagai pembimbing, mereka adalah teladan kita dan kita harus mengikuti mereka. Karena ketika kita berhaji, kita memerlukan petunjuk (dalal) untuk mencapai Ka'bah, para syaikh ini adalah petunjuk kita (dalal) menuju Allah dan Nabi kita", Al-'Asimiy' (1398, h. 499).

\section{Penutup}

a. Kesimpulan

Dari uraian penjelasan di atas, penulis dapat menarik beberapa kesimpulan, antara lain:

1. Bahwa Ibn Taymiyyah lahir dan tumbuh di zaman yang penuh gejolak yang menyebabkan Islam dan zaman keemasannya runtuh akibat perang salib dan serangan bangsa Mongol ke wilayah-wilayah Islam

2. Ibn Taymiyyah melakukan ijtihad dengan metode jalan tengah dan pemurnian 'aqidah yang sudah tercemar dan penuh dengan bid'ah, khurafat dan takhyul serta menyeru untuk kembali kepada Al-Qur'an, Sunnah dan praktik-praktik yang telah dilakukan oleh kaum salaf. Paham ini dilatarbelakangi oleh situasi dan kondisi terjadinya pertentangan antar golongan yang satu dengan golongan yang lain, sehingga umat Islam semakin terpuruk. Maka, Ibn Taymiyyah mendobrak kebekuan zaman yang terjadi kala itu. Ibn Taymiyyah memberikan kritik terhadap sufisme/tasawuf yakni memberikan kritikan pedas kepada ahli tasawuf falsafi dan penganut tarekat yang cenderung "lari" dari realitas kehidupan sosial "mundur" umat Islam dengan hanya mementingkan kebahagian dirinya sendiri dan lebih sibuk dengan ritual-ritualnya tarekatnya, serta para murid sangat taklid kepada sang mursyidnya.

b. Implikasi Penelitian

1. Pendekatan historis dalam mengungkap perjalanan intelektual Ibn Taymiyyah belumlah cukup, dibutuhkan pendekatan yang komprehensif sehingga dapat menggali latar belakang gagasannya. 
2. Penelitian ini hanya menyoroti satu aspek dari sekian aspek gagasan Ibn Taymiyyah. Oleh karena itu, dibutuhkan penelitian lebih lanjut berkaitan dengan gagasan Ibn Taymiyyah dari segi sosial-politik, sosial-ekonomi dan sosial-religi.

\section{DAFTAR PUSTAKA}

Afrohah. "Fundamentalisme: Korelasi Ideologi Fundamentalisme Dengan Ideologi Gerakan Islam Modern.” Al-Tahrir 18, no. 1 (2018).

Ahmad, La Ode Ismail dan Muhammad Amri. "Epistemologi Ibn Taymiyyah Dan Sistem Ijtihadnya Dalam Kitab Majmu Fatawa Dalam Jurnal.” Al-Ulum Vol. 19, no. I (2019).

Al-'Asimiy', Abd. al-Rahman Muhammad bin Qasim. Majmu’ Al-Fatawa Syaikh Al-Islam Ibnu Taymiyah. I. Saudi Arabia: Mamlakah Saudi Arabia, 1398.

Al-Uraifi, Muhammad Abdurrahman. Mauqif Ibn Taymiyah Min Sufiyah. Riyadl: Dar alMinhaj, n.d.

Baso, Ahmad. NU Studies: Pergolakan Pemikiran Antara Fundamentalisme Islam Dan Fundamentalisme Neo-Liberal. Jakarta: Erlangga, 2006.

Burhanuddin, Nunu. "Akar Dan Motif Fundamentalisme Islam: Reformulasi Tipologi Fundamentalisme Dan Prospeknya Di Indonesia." Wawasan: Jurnal Ilmiah Agama Dan Sosial Budaya 1, no. 2 (2016).

Esposito, Jhon L. Ensiklopedi Oxford: Dunia Islam Modern. Bandung: Mizan, 2002.

Fadl, Khalid Abou. El. Great Thaft: Wrestling Islam From The Extremists. New York: Harper San Fransisco, 2005.

Faza, Abrar M. Dawud. "Tasawuf Falsafi." Al-Hikmah: Jurnal Theosofi Dan Peradaban Islam 1, no. 1 (2019).

Harahap, Syahrin. Metodologi Studi Tokoh Pemikiran Islam. Jakarta: Istiqamah Mulya Press, 2006.

Idris, Abdul Fatah. "Pemikiran Ibn Qayyim Al-Jauziyyah Tentang Penggunaan Hadis Daif Dalam Istinbath Hukum.” Manahij: Jurnal Hukum Islam VII, no. 2 (2013).

Ikalson, Munahen. A Sufi Rube for Novies Diterjemahkan Oleh Yuliani Liputo Dengan Judul Menjadi Sufi. Bandung: Pustaka Hidayah, n.d.

Irham, dan Yudril Basith. "Revitalisasi Makna Guru Dan Ajaran Tasawuf Dalam Kerangka Pembentukan Karakter.” Ulul Albab 19, no. 1 (2018).

Iswahyudi. "Pengaruh Filsafat Terhadap Heteredoksi Teologi Islam." Al-Tahrir 17, no. 1 (2017).

Trimingham, J. Spencer. The Sufi Orders in Islam. London: Oxford University Press, 1973.

Kholil, Abdul Mun'im. “Jejak Metodologis Anti-Sufi: Analisis Kritis Pemikiran Sufisme Ibn Taymiyah.” Reflektika Vol. 13, no. No. 1 (2017).

Krawietz, Birgitand Georges Tamer., ed. Islamic Theology, Philosophy and Law: Debating Ibn Taymiyya and Ibn Qayyim Al-Jawziyya. 1st ed. German: de Gruyter, n.d. 
Madjid, Nurcholish. Islam: Doktrin Dan Perdaban. Jakarta: Paramadina, 2000.

—. Khazanah Intelektual Islam. Jakarta: Bulan Bintang, 1983.

Mahjuddin. Akhlak Tasawuf II. Jakarta: Kalam Mulia, 2012.

Rahman, Fazlur. Islam. II. Jakarta: Bina Aksara, 1992.

Rahmanu, Abid. "The Mistification of Puritants Islamic Law Epistemology In Profetic Social Science Perspective.” Episteme 13, no. 2 (2018).

Robinson, Case F. Islamic Civilazation in Thirty Lives The First 1.000 Years, Diterjemahkan Oleh Fahmy Yamani. Jakarta: Pustaka Alvabet, 2019.

Taymiyah, Ibn. Minhāj Al-Sunnah Al-Nabawiyah Fi Naqdh Kalām Al-Syi'ah Wa'lQadariyah. I-IV. Beirut: Dar al-Kutub al-'Ilmiyah, n.d.

Taymiyyah, Ibn. Majmu’ Rasa 'il Wa Masail. IV. Cairo: Al-Hisbah., n.d.

Usman, Muh. Ilham. "Sufisme Dan Neosufisme Dalam Pusaran Cendikiawan Muslim." TAHDIS 6, no. 1 (2015).

Washil, Izzuddin dan Ahmad Khairul Fata. "Pemikiran Teologis Kaum Salafi: Studi Pemikiran Kalam Ibn Taymiyyah." Ulul Albab 19, no. 2 (2018).

Washil, Izzuddin dan Ahmad Khairul Fata. "Pemikiran Ibn Taymiyyah Tentang Shari'ah Sebagai Tujuan Tasawuf." Teosofi: Jurnal Tasawuf Dan Pemikiran Islam 7, no. 2 (2017).

Yazid, Syaifulloh. "Melacak Dan Menyikapi Proyek Revivalisme Dalam Gerakan Fundamentalisme Islam." Kalam 11, no. 1 (2017).

Yusuf, Mundzirin. “Peradaban Dinasti Mamluk Di Mesir.” Thaqafiyyat 16, no. 2 (2015).

Zamzami, Mukhammad. "Rekonstruksi Pemikiran Dan Posisi Sufi-Antisufi Ibn Taymiyyah.” Teosofi: Jurnal Tasawuf Dan Pemikiran Islam 7, no. 2 (2017). 